\title{
Hágától Washingtonig - A magyar hivatalos statisztika kapcsolatai a nemzetközi szervezetekkel a kezdetektől 1947-ig
}

Rózso Dávid,

a KSH Könyvtár föigazgatóhelyettese

E-mail: David.Rozsa@ksh.hu
A hivatalos magyar statisztika szinte születése pillanatától a nemzetközi statisztikai élet része volt. A hazai szakemberek már az első években részt vettek a nemzetközi tudományos diskurzusban; figyelemmel kísérték a külföldön zajló statisztikai munkát, és a külföld is figyelemmel kísérte a magyart. A kapcsolatok igen hamar kiépültek valamennyi fontosabb nemzetközi szervezettel. A cikk ezek alakulását tekinti át a Központi Statisztikai Hivatal (KSH) fennállásának első nyolcvan évében.

TÁRGYSZÓ:

Statisztikatörténet.

Intézménytörténet.

Nemzetközi kapcsolatok.

DOI: $10.20311 /$ stat2017.11-12.hu1067 
A Földmívelés-, Ipar- és Kereskedelemügyi Minisztérium statisztikai szakosztályának megalakulását megelőzte Keleti Károlynak a hivatalos statisztika szervezése tárgyában Gorove István miniszterhez intézett emlékirata. Ebben elsődleges fontosságot tulajdonított a nemzetközi kapcsolatok kiépítésének. „Az elfogadandó szervezetnek olyannak kell lenni, melynek életbeléptetésével a magyar statistikai hivatal rögtön és egyenjogúan sorakozhatik a külföld hasonfajú legjobb intézeteihez, hogy az működésében mennyiségre nézve egyelöre talán csekély, de minőségre, tudományos becsre és használhatóságra nézve hasonló eredményeket tudjon felmutatni" írta (Bokor [1896] 19. old.). Majd ekként folytatta: „A közlésben és földolgozásban pedig oly alapokból kell indulnia a magyar statistikai hivatalnak, a minők külföldön nemcsak helyesnek bizonyultak, de általában el is fogadtattak; mert Magyarországnak nemcsak Ausztriával kell folyton érintkeznie, hanem egyenközüen kell haladnia a távolabb külfölddel is, különben statistikai adatok összehasonlítása, mi valamely országnak megismerésére elkerülhetetlenül szükséges, merö lehetetlen, legalább soha nem tanulságos." (Bokor [1896] 20. old.). Íme a nemzetközi összehasonlítások alapvetése 1867-böl. (És íme a KSH Könyvtár máig elevenen élő nemzetközi cserekapcsolatainak alapja: költségvetési tervezetében ugyanis Keleti a hazai szakemberek külföldi tapasztalatszerzésének, a nemzetközi konferenciák látogatásának fontossága mellett a külföldi évkönyvek, szakmonográfiák, folyóiratok beszerzésére is kitért.)

\section{A hivatalos statisztika nemzetközi kapcsolatainak kiépülése és megszilárdulása}

A hivatal a statisztikai kongresszusok révén kapcsolódott be a nemzetközi tudományos vérkeringésbe. Ezeket az összejöveteleket a belga Adolphe Quetelet ${ }^{1}$ elképzelése alapján hívták össze két-háromévente 1855 óta. Gyakorlati céljuk - Keleti Károly és Hunfalvy János megfogalmazásában - az volt, hogy „,a statistikai adatok feljegyzésébe, gyüjtésébe és összeállitásába a különbözö államokban egységes eljá-

\footnotetext{
${ }^{1}$ Adolphe Quetelet (1796-1874) belga matematikus, statisztikus, demográfus, csillagász, meteorológus, író, a statisztikai módszerek társadalomtudományi alkalmazásának kezdeményezője, a morálstatisztika úttörője, a nemzetközi összehasonlító statisztika és a nemzetközi statisztikai kongresszusok atyja. Huszonnégy éves korától a belga tudományos akadémia tagja, 1832 és 1834 között elnöke volt. Keleti Károly a statisztika terén „küzködők közül egész fejjel kimagasló herosnak” tartotta, aki „nemcsak Belgiumé volt, ő a nemzetközi tudományé vala és általa mindnyájunké” (Keleti [1875] 3., 24. old.).
}

Statisztikai Szemle, 95. évfolyam 11-12. szóm 
rást és rendszert hozzanak be" (Keleti-Hunfalvy [1873] 13. old.). 1857-ben Bécsben Fényes Elek, 1863-ban Berlinben Weninger Vince személyében magyar tudós is részt vett az eseményen, de mindkettő a Magyar Tudományos Akadémia küldötteként.

A nemzetközi statisztikai kongresszusok föbb adatai

(fö)

\begin{tabular}{l|c|c|c}
\hline \multirow{2}{*}{\multicolumn{1}{c}{ A kongresszus sorszáma, helyszíne és időpontja }} & \multicolumn{2}{|c}{ Résztvevök létszáma } \\
\cline { 2 - 4 } & Hazai & Külföldi & Összesen \\
\hline \multirow{2}{*}{ I. Brüsszel, 1853. szeptember 19-22. } & 88 & 65 & 153 \\
\hline II. Párizs, 1855. szeptember 10-15. & 203 & 108 & 311 \\
\hline III. Bécs, 1857. augusztus 31. - szeptember 5.* & 464 & 78 & 542 \\
\hline IV. London, 1860. július 16-21. & 505 & 81 & 586 \\
\hline V. Berlin, 1863. szeptember 4-12. & 350 & 127 & 477 \\
\hline VI. Firenze, 1867. szeptember 29. - október 5. & 666 & 85 & 751 \\
\hline VII. Hága, 1869. szeptember 6-11. & 372 & 116 & 636 \\
\hline VIII. Szentpétervár, 1872. augusztus 22-29.** & 511 & 125 & 442 \\
\hline IX. Budapest, 1876. augusztus 29. - szeptember 11. & 267 & 175 & \\
\hline
\end{tabular}

* Brown [1858] 10. old. szerint csak 487-en vettek részt a kongresszuson, közülük 427-en belföldröl, 370en Bécsböl.

** A helyi időszámítás szerint 1872. augusztus 10-17. Az általában jól tájékozott Ernst Mischler (18571912) a hivatalos statisztika történetét feldolgozó kézikönyvében (Mischler [1892] 286. old.) 360 hazai és 128 külföldi, összesen tehát 488 küldöttet említ. (Ezt az adatot vette át Nixon [1960] 6-7. old. is.) Ennek forrásértéke különösen annak fényében kérdéses, hogy csak négy szentpétervári szekcióról van tudomása (Mischler [1892] 288. old.), holott más, egymástól függetlenül keletkezett források szerint öt ülésezett.

Megjegyzés. Köszönöm Horváth Balázsnak a táblázat összeállításához nyújtott segítségét.

Forrás: Saját szerkesztés Brian [1990], Brown [1854] 93. old., [1858] 16. old., [1864] 195. old., [1868] 11. old., [1869] 391. old., [1872] 431. old., Hammack [1861] 7. old., Keleti-Hunfalvy [1873] 4. old., Levi [1856] 1. old., Mischler [1892] 286. old. és Mouat [1876] 628. old. alapján.

A magyar hivatalos statisztikát első ízben az 1869-es hágai kongresszuson képviselte Keleti és Hunfalvy. Az értekezleten a porosz Ernst Engel javaslatára döntés született az összehasonlító nemzetközi statisztika megteremtéséről. Ennek keretében huszonnégy nagy témakör kidolgozásával bízták meg az egyes hivatalokat. A magyar szakemberekre a szőlészeti statisztika összeállításának, módszertana kidolgozá-

${ }^{2}$ Ernst Engel (1821-1896) német statisztikus, közgazdász, 1850 és 1858 között a szász, 1860-tól Bismarckkal való 1882-es összekülönbözéséig a porosz statisztikai hivatal vezetője, 1867 és 1870 között a porosz parlament tagja. Többek között a népszámlálások módszertanával, a háztartások fogyasztásának mérésével és iparstatisztikával foglalkozott (Blenck [1897]). Keleti Károly értékelése szerint Quetelet halála után a „talán legkitünőbb statistikus" volt (Keleti [1875] 21. old.). 
sának feladata jutott. Ez tekinthető a hazai statisztika első komoly nemzetközi elismerésének. (Többek között erre hivatkozva szorgalmazhatta Keleti a statisztikai osztály önálló hivatallá emelését, ami 1871-ben be is következett.) A történeti hüség kedvéért megjegyzendő, hogy a szőlészeti statisztika bortermelésre vonatkozó adatfelvételét meg kellett ismételni, mivel első alkalommal a becsült érték mindössze tíz százalékát kapták eredményként. Ráadásul a külföldi adatok sem érkeztek meg soha. Ahogy Keleti Károly fogalmazott: „A kölcsönös adatszolgáltatás az egyes fejezetekre nézve korán sem foly oly bőségesen, mint az illető fejezet vállalkozója óhajtja. Ennek pedig természetes oka a statistikának az egyes országok szerint különböző állapotában keresendő.” (Keleti [1874] 7. old.) Végül csak a Magyarországgal foglalkozó kötet jelenhetett meg 1875-ben. Rögzítsük: a „Magyarország szőlőszeti statistikája 1860-1873" (franciául Viticulture de la Hongrie 1860-1873) címü kiadvánnyal teljesítette a hivatalos statisztikai szolgálat első nemzetközi kötelezettségét.

A Hágában meghozott döntés értelmében a következő, szentpétervári kongreszszust 1871-ben kellett volna megtartani, ám a cári kormány egy évvel elhalasztotta a szervezést. A végül 1872 augusztusában összeült értekezleten 636 küldött jelent meg, csak Oroszországból 511 fő. Az európai országokon kívül az Egyesült Államok, Brazília, Costa Rica, Egyiptom és Japán is képviseltette magát. Magyarországról Keleti és Hunfalvy mellett - még hatan vettek részt nem hivatalos küldöttként. Köztük volt Körösy József, a fővárosi statisztikai hivatal vezetője, aki az előtanácskozások során berlini kollégájával együtt megbízást kapott az összehasonlító nagyvárosi statisztika módszertanának kidolgozására. A kongresszus Pjotr Szemjonov elnökletével ekkor felállított állandó bizottságában első ízben Keleti és Körösy képviselte Magyarországot. A szakmai kérdéseket később öt szekcióban vitatták meg; a legfontosabb eredmények a népszámlálási szekcióban születtek, ahol egyebek mellett megfogalmazták a tényleges, a letelepedett és a törvényszerủ népesség definícióját, továbbá arról is határoztak, hogy a cenzusokat a 0-val végződő években, lehetőleg egy nap alatt, de legalábbis valamely eszmei időpontra vonatkozóan, egyéni számlálólapokat alkalmazva kell végrehajtani (Keleti-Hunfalvy [1873]).

Szentpéterváron (majd ezt megerősítendő az állandó bizottság következő évi bécsi ülésén) született döntés arról is, hogy a következö, 1876-os kilencedik nemzetközi összejövetelt Budapest rendezheti meg. A magyar föváros a függetlenségének századik évfordulójára készülő Egyesült Államokat, valamint Svájcot utasította maga mögé. Ebben felettébb fontos szerepet játszott Quetelet, „ő mutatván ki fényes eloquentiával, mennyi teendője van még a kongressusoknak Európában s hogy annak egyik polgárosodott országában kell keresniök a székhelyet, nemcsak a jövendö kongressus, de az azt követő állandó bizottsági elnökség számára is, ha szakítani nem

\footnotetext{
${ }^{3}$ Pjotr Petrovics Szemjonov-Tan-Sanszkij (1827-1914) orosz földrajztudós, felfedező, statisztikus, botanikus, entomológus, az orosz hivatalos statisztika vezetője 1864 és 1891 között. Fáradhatatlan munkálkodásának köszönhetően valósulhatott meg az első oroszországi népszámlálás 1897-ben.
}

Statisztikai Szemle, 95. évfolyam 11-12. szám 
akarván hagyományukkal, új térre sodortatják magukat, mielött a kezökre bízottat teljesen megmüvelték volna" (Keleti [1875] 23. old.).

Az 1876-os budapesti kongresszus a Balkánon kirobbant törökellenes felkelések és az érlelődő újabb orosz-török háború árnyékában zajlott, de - szemben a néhány hónappal későbbi állapotokkal, amikor mindent ,az európai hadi készülődések általános zavara” uralt - még „,volt elég higgadtság a tudósokban, s elég nyugalom az összes európai mivelt államokban arra, hogy politikai okok épen nem gátolták a IX-ik nemzetközi statisztikai kongresszus szerencsés és sikeres lefolyását" (Vasárnapi Ujság [1876b] 754. old.). Az első résztvevők augusztus 29-én érkeztek vonaton és gőzhajón. A vendégeket Vácott Greguss Ágost, Hunfalvy Pál és Körösy József, Budapesten Kamermayer Károly polgármester és Keleti Károly fogadta. A fơvárosi sajtó kitüntetett érdeklődéssel kísérte a rendezvényt (és a szeptember 4-én megnyitott őstörténelmi és embertani kongresszust). „E megtiszteltetés jelentőségét éreznie kell minden müvelt magyarnak. Nyomunk már valamit a latban a világ elött szaktudomány dolgában is" jegyezte meg a Vasárnapi Ujság publicistája (Borostyáni [1876a] 570. old.). Ugyanő egy későbbi cikkében így írt a résztvevők számára szervezett hajókirándulásról: „A födélzet szinte szükké vált a nemzetközi társaság befogadására. Ott voltak mindannyian, kik a kongresszus büszkeségét képezik: Farr ${ }^{4}$ és Levasseur, ${ }^{5}$ Block $^{6}$ és Correnti, Gneist $^{8}$ és Semenow, Stein ${ }^{9}$ és Yvernès ${ }^{10}$ - francziák, németek, angolok, oroszok, svédek, olaszok, belgák, osztrákok, dánok, spanyolok s hollandok vegyesen. Egy darab Európa egy födélzet keskeny területén.” (Borostyáni [1876b]).

A kongresszus hivatalos értesítője Greguss Ágost szerkesztésében látott napvilágot augusztus 30-án. Ugyanekkor tanácskozott első ízben az állandó bizottság, majd a tagok előkészítő ülésen vettek részt. A másnapi ankéton a különböző államok öszszehasonlító népességi adatairól, az európai polgári és kereskedelmi törvénykezésröl,

\footnotetext{
${ }^{4}$ William Farr (1807-1883) angol epidemiológus, az egészségügyi statisztika egyik megalapítója, John Snow (1813-1858) munkatársaként a kolera terjedésének kutatója, 1855-töl a Királyi Természettudományos Társaság (Royal Society) tagja.

${ }^{5}$ Pierre Émile Levasseur (1828-1911) francia közgazdász, történész, földrajztudós, statisztikus, 1871-től Henri Baudrillart (1821-1892) utódaként a Collège de France oktatója, az IIS ([Institut international de statistique] vagy 1948-ig nem hivatalosan ISI [International Statistical Institute - Nemzetközi Statisztikai Intézet]) alapító tagja, 1885-től haláláig alelnöke, 1894-től a Svéd Királyi Tudományos Akadémia tagja, a Francia Földrajzi Társaság (Société de géographie) tiszteletbeli elnöke, a Párizsi Statisztikai Társaság (Société de statistique de Paris) elnöke. A gazdaságföldrajz egyik első nagyhatású művelője.

${ }^{6}$ Maurice Block (1816-1901) porosz születésủ francia statisztikus, közgazdász, 1856-tól haláláig a politikai gazdaságtani és statisztikai évkönyv, a L'Annuaire de l'economie politique et de la statistique szerkesztője. A budapesti kongresszuson Japán delegáltjaként vett részt.

${ }^{7}$ Cesare Correnti (1815-1888) olasz államférfi, 1867-ben, majd 1869 és 1872 között hazája oktatásügyi minisztere.

${ }^{8}$ Rudolf von Gneist (1816-1895) porosz jogtudós, politikus. Föként alkotmányjoggal és -történettel foglalkozott.

${ }^{9}$ Lorenz von Stein (1815-1890) német államjogtudós, szociológus és nemzetgazdász, a közigazgatástudomány elöfutára, a „társadalmi mozgalom” terminus megalkotója. 1855 és 1885 között a bécsi egyetemen oktatott politikai gazdaságtant.

${ }^{10}$ Émile Yvernès (1830-1899) francia jogtudós, statisztikus, az igazságügy-minisztérium statisztikai részlegének és bünügyi nyilvántartásainak vezetője. A morálstatisztika kiemelkedő művelője volt.
} 
a takarékpénztárakról, a nemzetközi tengeri hajózásról és az első japán statisztikai összegzésről hangzottak el referátumok. Körösy negyvenegy nagyváros összehasonlító statisztikáját prezentálta, míg Keleti az erdészeti és a szőlőmüvelési statisztikáról beszélt. A szeptember 1-jei ünnepélyes megnyitónak az Akadémia díszterme adott otthont József föherceg, Wenckheim Béla a király személye körüli miniszter (volt miniszterelnök), Perczel Béla igazságügy-, Szende Béla honvédelmi és Trefort Ágoston vallás- és közoktatásügyi miniszter, valamint Haynald Lajos kalocsai érsek és Hollán Ernő tábornok (volt honvédelmi államtitkár) jelenlétében. A köszöntőket a statisztikatudomány nemrég elhunyt nagyjairól (többek között Quetelet-röl és Fényes Elekröl) megemlékező beszédek követték. A kongresszusok történetében elöször grafikonokat, térképeket és statisztikai műveket kiállító tárlat kísérte a rendezvényt a képzőművészeti társulat helyiségeiben. Ennek gondozása és katalógusának összeállítása a híres utazóra és geográfusra, Déchy Mórra hárult (Vasárnapi Ujság [1876a]). A Fövárosi Lapok tudósítója szerint „magokat a kongresszus tagjait is meglepte az anyag bősége és érdekes volta, a kiállítás disze és célszerü berendezése által" (Fövárosi Lapok [1876]).

A következő egy hétben hat szakosztályban és a plenáris üléseken zajlottak a megbeszélések. Az első szekciót a statisztika- és a népesedéselméletnek szentelték a következő témákkal: a statisztika oktatása az elemi és a középiskolai, valamint a felsőfokú képzésben; a halandósági táblák szerkesztésének egzakt módszerei; a nagyvárosok népmozgalmáról készítendő rendszeres közlemények szerkezete, öszszehasonlíthatóvá tétele. A második szekcióban az igazságügyi, a harmadikban az orvosi és a közegészségügyi statisztika került napirendre, az utóbbiban a járványos betegségek nemzetközi statisztikájáról, a koleráról, valamint a fürdő- és ásványvízstatisztikáról szóló blokkal. A negyedik csoportot a mezőgazdasági és az erdészeti kérdéskörök (az agrárstatisztika, az erdőstatisztika és a mezőgazdasági meteorológia) alkották. A kettébontott gazdaságstatisztikai szekcióban valóságos tématorlódással kellett szembesülniük a résztvevőknek: szó esett a nemzeti ipar helyzetéröl, a munkavégzés közben bekövetkezett balesetekről, halálesetekről és az ezek elkerülése érdekében meghozandó intézkedésekről, az egyesületi és a vállalati statisztikáról, a vagyonmérlegek és a külkereskedelmi táblák szerkesztésének gyakorlatáról, a vasúti és a belkereskedelemi statisztikáról, végül a nagyvárosok pénzügyeinek statisztikájáról. Ezt az ambiciózus (kevésbé visszafogott jelzővel: zsúfolt) programot - a szervezők érdemeinek elismerése mellett - viszonylag sok bírálat érte, hiszen a rendelkezésre álló időben képtelenség volt valamennyi felvetett problémát kimerítően megtárgyalni. A kritikusok azzal is tisztában voltak ugyanakkor, hogy az efféle gigantikus rendezvénysorozatok természetes velejárója, hogy elődeiktől örökölnek és utódaikra hagyományoznak megoldatlan kérdéseket (Mouat [1876] 633-634. old.).

Az 1870-es évek végére a nemzetközi statisztikai kongresszusok rendszere - nem kis részben a francia-német politikai ellentétek miatt - válságba jutott, az állandó 
bizottság 1878 után már nem is ülésezett. Az alapvető szakmai problémákat a szentpétervári főszervezö, Szemjonov a következőkben állapította meg: a kongresszusok nemzetközisége erősen megkérdőjelezhetö, amíg a résztvevők túlnyomó többsége a szervező országból érkezik, és a felvetett témák kizárólag a szintén hazai szervezőbizottságtól függenek; a statisztikai módszertani ajánlásokat nem előzik meg az egyes nemzetek gazdasági-társadalmi sajátosságait feltérképező vizsgálatok; nincs folyamatosság a kongresszusok munkájában; nem áll rendelkezésre információ a nemzetközi határozatokban foglaltak alkalmazásáról. Hasonló jelenségekre hívta fel a figyelmet Frederic J. Mouat, ${ }^{11}$ az LSS (Statistical Society of London - Londoni Statisztikai Társaság) külügyi titkára a budapesti konferencia után készített jelentésében (Mouat [1876] 631-633. old.).

Az LSS 1884-ben kongresszussal készült megünnepelni alapításának félévszázados évfordulóját, és ebből az alkalomból javaslatot kívánt tenni egy nemzetközi statisztikai társaság létrehozására is. Az eseményt a következő esztendőre halasztották ugyan, de az eredeti elképzelésről nem mondtak le. (Sőt, a téma a Párizsi Statisztikai Társaság közvetlenül ezt megelöző huszonötödik jubileumi konferenciáján is napirendre került.) Az 1885. június 22-24-ei tanácskozáson tizenkét ország képviselői jelentek meg (a németek távol maradtak). Vitaindító előadásában az osztrák $\mathrm{Neu}$ mann-Spallart ${ }^{12}$ a szabad, hivatali kötelmektöl mentes szervezeti forma, de a hivatalos és az akadémiai statisztikában is vezető szerepet játszó tagság mellett érvelt. Ennek jegyében hozta létre huszonkét alapító tag (köztük három magyar: Keleti, Körösy és Hunfalvy) az IIS-t mint nem hivatalos tudományos szervezetet (Nixon [1960] 11-16. old.). Az Osztrák Központi Statisztikai Bizottság elnöke, InamaSternegg ${ }^{13}$ azon javaslatát, hogy az intézeten belül állítsanak fel külön testületet a hivatalos statisztikával foglalkozók számára az egyes kormányoknak szóló ajánlások kidolgozása céljából, nem szavazták meg. ${ }^{14}$

\footnotetext{
${ }^{11}$ Frederic J. Mouat (1816-1897) brit kutatóorvos, kémikus, az első urdu nyelvủ anatómiai atlasz megalkotója, az indiai egészségügyi és börtönreform szorgalmazója. 1890 és 1892 között betöltötte az 1887-ben RSS-sé (Royal Statistical Society - Királyi Statisztikai Társaság) átnevezett statisztikai tudományos testület elnöki posztját.

${ }^{12}$ Franz Xaver von Neumann-Spallart (1837-1888) osztrák közgazdász, statisztikus, a bécsi egyetem professzora, az Osztrák Császári és Királyi Központi Statisztikai Bizottság tagja, az IIS alapító tagja, 1885-től haláláig alelnöke. 1886-ban a Szentpétervári Birodalmi Tudományos Akadémia levelező tagjává választották (Nixon [1960] 160. old.).

${ }^{13}$ Karl Theodor von Inama-Sternegg (1843-1908) osztrák államtudós, statisztikus, gazdaságtörténész, 1881-től az osztrák hivatalos statisztika vezetője. Irányította az 1880-as, az 1890-es és az 1900-as osztrák népszámlálást, valamint 1895-től a migrációs adatgyüjtéseket. Az IIS alapító tagja, 1899-től haláláig elnöke volt. Tanított Innsbruckban, Prágában és Bécsben, díszdoktorává avatta a Cambridge-i, a Csernyivci és a Krakkói Egyetem. 1877-ben a bécsi tudományos akadémia levelező, 1899-ben rendes tagja lett (Juraschek [1909], [Nixon [1960] 159. old.).

${ }^{14}$ Az IAOS (International Association for Official Statistics - Hivatalos Statisztika Nemzetközi Társasága) végül 1985-ben jött létre az intézet kebelében a KSH akkori elnöke, Nyitrai Ferencné javaslatára (Szilágyi [2012] 738. old.).
}

Statisztikai Szemle, 95. évfolyam 11-12. szóm 
Az IIS 1887 és 1947 között megrendezett világkonferenciáinak föbb adatai

(fö)

\begin{tabular}{|c|c|c|}
\hline \multirow{2}{*}{ A konferencia sorszáma, helyszíne és időpontja } & \multicolumn{2}{|c|}{ A résztvevők létszáma } \\
\hline & az IIS tagjai közül & összesen \\
\hline I. Róma, 1887. április 12-16. & 56 & 92 \\
\hline II. Párizs, 1889. szeptember 2-6. & 39 & 66 \\
\hline III. Bécs, 1891. szeptember 28. - október 3. & 62 & 81 \\
\hline IV. Chicago, 1893. szeptember 11-15. & 22 & 79 \\
\hline V. Bern, 1895. augusztus 26-31. & 46 & 106 \\
\hline VI. Szentpétervár, 1897. augusztus 30. - szeptember 4. & 46 & 94 \\
\hline VII. Krisztiánia (Oslo), 1899. szeptember 1-9. & 35 & 108 \\
\hline VIII. Budapest, 1901. szeptember 29. - október 4. & 59 & 138 \\
\hline IX. Berlin, 1903. szeptember 21-25. & 80 & 245 \\
\hline X. London, 1905. július 31. - augusztus 4. & 65 & 97 \\
\hline XI. Koppenhága, 1907. augusztus 26-31. & 69 & 100 \\
\hline XII. Párizs, 1909. július 4-10. & 80 & 149 \\
\hline XIII. Hága, 1911. szeptember 4-8. & 72 & 125 \\
\hline XIV. Bécs, 1913. szeptember 9-13. & 80 & 166 \\
\hline XV. Brüsszel, 1923. október 1-6. & 55 & 119 \\
\hline XVI. Róma, 1925. szeptember 26. - október 2. & 68 & 203 \\
\hline XVII. Kairó, 1927. december 29. - 1928. január 5. & 60 & 162 \\
\hline XVIII. Varsó, 1929. augusztus 21-24. & 58 & 169 \\
\hline XIX. Tokió, 1930. szeptember 15-25. & 42 & 157 \\
\hline XX. Madrid, 1931. szeptember 14-20. & 51 & 123 \\
\hline XXI. Mexikóváros, 1933. október 11-14. & 38 & 95 \\
\hline XXII. London, 1934. április 16-20. & 75 & 113 \\
\hline XXIII. Athén, 1936. szeptember 28. - október 1. & 71 & 126 \\
\hline XXIV. Prága, 1938. szeptember $12-13 .^{*}$ & 52 & 145 \\
\hline XXV. Washington, 1947. szeptember 6-18. & 43 & 614 \\
\hline
\end{tabular}

* A konferencia az eredeti tervek szerint szeptember 17-én zárult volna, de a politikai helyzet miatt már a második napon berekesztették.

Forrás: Saját szerkesztés Nixon [1960] 187. old. és a konferenciák kötetei alapján.

A magyar kormány Láng Lajos által tolmácsolt meghívását elfogadva, hivatalos statisztikánk újabb nemzetközi elismeréseként 1901-ben Budapesten rendezték meg az IIS nyolcadik konferenciáját, amelyen a korábbiaknál sokkal több, százharmincnyolc szakember jelent meg. A szeptember 29-ei ünnepi megnyitó helye ezúttal a 
förendiház ülésterme volt. ${ }^{15}$ A díszelnöki pozíciót Hegedüs Sándor kereskedelemügyi miniszter vállalta el; mellette Inama-Sternegg és a szervezőbizottság elnöke, Láng Lajos foglalt helyet, aki az év elején fiatalon elhunyt Jekelfalussy Józseftöl vette át a feladatot (Budapesti Hírlap [1901a]). A következő napok szaktanácskozásai három szekcióban folytak: a demográfiaiban, a közgazdaságiban, valamint a jogi és közigazgatásiban. Az átfogó témájú előadásokat plenáris ülések keretében tárgyalták. A kongresszus egyik legnagyobb visszhangot kiváltott bejelentése Körösy Józsefhez füződik, aki Hegedüs miniszter támogatásával az 1900-as népszámlálások adataiból kívánt világatlaszt szerkeszteni. A közel ötven előadásból tizennégyet tartottak magyarok, akik közül Körösynek a főváros termékenységi viszonyairól tartott referátuma váltotta ki a legnagyobb szakmai elismerést (Budapesti Hirlap [1901b] 10. old.). Ugyanő még egy, a részvénytársaságok számbavételét taglaló előadással is jelentkezett. A további magyar felszólalók közül Bedö Albert az erdészeti statisztikáról, Chyzer Kornél az elmebetegek statisztikájáról, Fellner Frigyes a nemzeti vagyon becsléséröl, Hegyeshalmy Lajos az 1899-es országos iparstatisztikai felvételek módszertanáról, Hennyey Vilmos postaigazgató a magyar postastatisztika szervezetéről, Mandelló Gyula a mezőgazdasági fizetésekről, Ráth Zoltán a házas termékenységröl, valamint az 1900-ban újjászervezett hazai bünügyi statisztikáról, Szterényi József a magyar iparpolitikáról, Thirring Gusztáv a nemzetközi vándorlási statisztikáról, Vargha Gyula az egyes országok külkereskedelmi forgalma összehasonlításának problémáiról, Vizaknai Antal a századfordulós népszámlálásokban tükröződő társadalmigazdasági viszonyokról beszélt (Szabó [1942] 44-45. old.).

Az első világháború előtt az IIS-éihez hasonló nagyságrendű nemzetközi összejövetelek voltak a közegészségügyi és demográfiai kongresszusok, amelyekből 1878 és 1913 között tizenhármat rendeztek. Jóllehet, ezeken a rendezvényeken a témák töredéke volt csupán statisztikai vagy demográfiai vonatkozású, így is figyelemre méltó mennyiségben tárgyaltak népességtörténeti, módszertani vagy akár a testi-szellemi fogyatkozásokkal kapcsolatos kérdésköröket. Keleti Károly és Kőrösy József már az első, a világkiállítást kísérő párizsi értekezleten is jelen volt (nota bene, előbbi emellett a szintén itt ülésező Nemzetközi Statisztikai Kongresszusok Állandó Bizottságát is elnökölte). Ismét a magyar tudományosság elismerését mutatja, hogy az 1891-es londoni összejövetelen Chicagóval szemben Budapestnek ítélték a következő nemzetközi demográfiai kongresszus rendezési jogát. Az 1894 szeptemberében Ferenc József védnöksége alatt lebonyolított eseményen huszonhat szakosztályban összesen nyolcszázhatvanhét előadás hangzott el. A kongresszus rendes tagjainak névjegyzékén 2239 személy szerepel, a női tagok száma 312 (Gerlóczy [1895] 172-236. old., Kármán [1969] 177-184. old.).

\footnotetext{
${ }^{15}$ A kongresszusról több téves információt közölt a sajtó. A Budapesti Hirlap a résztvevők számát becsülte kétszáz före (Budapesti Hirlap [1901a] 6. old.), a Pesti Napló a nyitóülést helyezte át a Földtani Intézetbe (Pesti Napló [1901] 3. old.).
}

Statisztikai Szemle, 95. évfolụam 11-12. szám 


\section{A két világháború között}

Az első világháború után, 1919. június 28-án életre hívott Nemzetek Szövetsége első teendői közé tartozott, hogy konferenciát hívjon össze Londonba a nemzetközi statisztikai együttmüködés kereteinek kialakításáról. Emellett az is deklarált célja volt, hogy a munkájához szükséges adatok összegyüjtése érdekében saját statisztikai szervezetet építsen ki. Miután 1920 elején a szervezet végrehajtó testülete, a négy állandó és négy ideiglenes taggal rendelkező Tanács is megalakult, létrehozták a Nemzetközi Statisztikai Bizottságot, amelynek első, párizsi ülésére 1920 októberében került sor (Nixon [1960] 27-28. old.). A testület a későbbiekben a csatlakozott országok nemzeti hivatalait adatszolgáltatásra kötelezte. Ezekből állította össze nagyszámú publikációját, köztük a Nemzetközi statisztikai évkönyvet. Feladatának tekintette a statisztikai módszerek, fogalmak és gyakorlat egységesítését. Magyarország - amely 1922 és 1939 között volt a Nemzetek Szövetségének tagja - szintén részt vett ebben a munkában. 1927-ben határozta el a világgazdasági konferencia az egységes vámtarifa kidolgozását. Ennek céljából öttagú bizottságot hoztak létre, amely a Magyarországon alkalmazott csoportosításokat találta a legmegfelelőbbnek. Az általa kialakított vámtarifaosztályozási rendszer a magyarral igen sok rokon vonást mutatott.

1928 novemberében-decemberében Genfben két és fél hetes értekezletet tartott negyven állam száznegyven statisztikusa. A magyar kormány részéről a KSH aligazgatója, Konkoly Thege Gyula vett részt az eseményen, amelyen döntöttek a külkereskedelmi, a foglalkozási, a mezőgazdasági és az iparstatisztika fogalmainak és módszereinek egységesítéséröl, a kimutatások azonos időszakra vonatkozó elkészítéséről és kicseréléséről. Ez a statisztika genfi konvenciója (a XIX-XX. század folyamán több azonos elnevezésú egyezmény is született ettől teljesen eltérő témákban). A konvenciót aláíró országok egyegy küldöttet delegálhattak abba a szakértői bizottságba, amely az egységesítési folyamatot volt hivatva felügyelni. A magyar statisztikai rendszer és praxis összehasonlítását a genfi ajánlásokkal igen hamar elvégezték. Konkoly Thege a Magyar Statisztikai Szemle 1929. szeptemberi számában ismertette a vizsgálat eredményét. Konklúziója: „Magyarországnak azokat a gazdaságstatisztikáit, amelyek a termelésnek, iparnak vagy forgalomnak oly ágazataira vonatkoznak, amelyeknek az országban jelentős szerepük van, legfeljebb csak kiegészíteni kell, lényegesebb módosításuk úgyszólván nem is jöhet szóba.” Végső soron megállapítható, hogy „Magyarország - mint minden tudomány terén - még a statisztika terén is Nyugat-Európának oly bástyájává lett, mint amilyen volt a harc terén a középkorban" (Konkoly Thege [1929] 1007-1008. old.).

Gyümölcsöző kapcsolat alakult ki a KSH és az 1905-ben megalapított IIA (Institut international d'agriculture - Nemzetközi Mezögazdasági Intézet) között is, A nemzetközi agrárstatisztikát tárgyaló közgyüléseken a magyar hivatalos statisztika képviselője mindig jelen volt. Magyarország azon negyvenhat állam közé tartozott,

Statisztikai Szemle, 95. évfolyam 11-12. szám 
amely elfogadta és végrehajtotta az intézetnek az azonos módszerekkel végrehajtandó agrárcenzusokról szóló 1928. októberi határozatát. Az IIA megbízásából készítette el Konkoly Thege 1928-ban a magyar mezőgazdasági statisztika szervezetéröl szóló „La statistique agricole en Hongrie” címü munkáját (Konkoly Thege [1937] 253. old., Révfalvi [1998] 110. old.).

A két világháború között a nemzetközi statisztikai életben sokáig elsősorban a gazdasági kérdések álltak előtérben. Az érdeklődés az 1920-as évek második felében fordult a népesedési problémák felé. Ez vezetett 1928-ban a mai IUSSP (International Union for the Scientific Study of Population - Nemzetközi Népességtudományi Unió), akkor még International Union for the Scientific Investigation of Population Problems (L'Union internationale pour l'étude scientifique des problèmes de population) elnevezésủ elődjének létrejöttéhez. Ennek 1947-ig nem lehettek egyéni tagjai; az egyesületi tevékenységet az egyes nemzeti csoportokon belül folytatták. Az unió munkájába 1936-ban kapcsolódott be a Balás Károly, Elekes Dezsö, Kovács Alajos, Schneller Károly, Szél Tivadar és Thirring Lajos által a Magyar Statisztikai Társaságon belül megalapított csoport (Révfalvi [1998] 114. old., Thirring [1958] 314-315. old.), amelynek tevékenységét Thirring Lajos foglalta össze máig kiadatlan visszaemlékezéseiben (Thirring [1978] 56-61. old.).

Az IIS taglistáján is folyamatosan gyarapodott a hazai nevek száma. 1929-ben nyolcan viselték a tiszteletbeli tag címet, köztük egy magyar: Földes Béla. A rendes tagok közül ugyanebben az évben heten, 1938-ban már kilencen voltak magyarok (Nixon [1960] 185. old., Révfalvi [1998] 108. old.). ${ }^{16}$

3. táblázat

Az IIS 1885 és 1939 között megválasztott magyar tagjai a választás éve szerint

\begin{tabular}{|c|c|c|c|}
\hline Választás éve & Az IIS tagja & Választás éve & Az IIS tagja \\
\hline 1885 & $\begin{array}{l}\text { Hunfalvy János, Jekelfalussy József, Kautz Gyula, } \\
\text { Keleti Károly, Kőrösy József, Láng Lajos }\end{array}$ & 1924 & Buday László \\
\hline 1886 & Földes Béla, Meltzl Oszkár & 1925 & Szabóky Alajos \\
\hline 1901 & Mandelló Gyula, Vargha Gyula & 1927 & Kovács Alajos \\
\hline 1902 & Ráth Zoltán & 1929 & Illyefalvi I. Lajos \\
\hline 1903 & Thirring Gusztáv & 1933 & Kenéz Béla \\
\hline 1905 & Vizaknai Antal & 1935 & Laky Dezső \\
\hline 1909 & Fellner Frigyes & 1937 & Konkoly Thege Gyula \\
\hline 1913 & Teleszky János & 1939 & Dobrovits Sándor \\
\hline
\end{tabular}

Forrás: Saját szerkesztés Stemerdink [2003] alapján.

${ }^{16}$ Eddig egyébként hetvennégy magyar statisztikust választottak az intézet tagjává, ami a valaha volt teljes taglétszám közel 2 százalékát jelenti (Stemerdink [2003] 84. old., Szilágyi [2012] 733. old.). 
Bár az egész világot foglalkoztató események a megelöző évtizedekben sem hagyták érintetlenül a nemzetközi tudományos tanácskozások hangulatát és lefolyását, az 1930-as évek második felében ennek új dimenzióival ismerkedhettek meg a kutatói közösség tagjai. Az 1935. augusztus 26. és szeptember 1. közötti berlini népességtudományi kongresszust - az egy évvel később megrendezett nyári olimpiai játékoknál nyilván jóval kisebb mértékben, de - igyekezett propagandacélokra felhasználni a nemzetiszocialista rezsim. A rendezvényt ,tüntető támogatásban részesítették”, az ünnepélyes megnyitót „az egykori thüringiai miniszter és purifikátor, a rendkívül nagy erkölcsi súllyal rendelkező Frick belügyminiszter” tartotta, és a „vezényszószerüen felzengő üdvkiáltások” hatása alól még a „,nagy rivális nemzet fia”, a többszörös francia miniszter, Adolphe Landry sem tudta kivonni magát (Schneller [1936] 3. old.). Az IIS 1938. szeptemberi prágai ülésszaka fél évvel az Anschluss után, a német fenyegetés rémétől kísértve már be sem tudta teljesíteni küldetését: a tekintélyes létszámú, a hivatalos és az egyetemi statisztika jeles képviselöit felvonultató magyar küldöttség például ,a viszonyok kedvezőtlen alakulása következtében” a legelső tanácskozási nap végén hazautazott, majd másnap be is rekesztették a kongresszust (Magyar Statisztikai Szemle [1938] 854. old.). A nemzetközi statisztikai kapcsolatokban 1938 után hosszú szünet következett.

\section{A „statisztikai elsötétítés” után}

Mike Gyula második világháború utáni leírásából tudjuk, hogy a KSH-ban az emberveszteségek, az anyagi és az épületkárok ellenére már 1945 tavaszán újraindult a szakmai munka (Mike [1947] 54. old.). Majd 1947 szeptemberében, az „évtizedes statisztikai elsötétítés" végén az Elekes Dezső KSH-elnökből és Bene Lajos székesfővárosi statisztikai hivatali vezetőből álló kétfős magyar statisztikusküldöttség is megjelent az IIS washingtoni ülésszakán, az első nemzetközi konferencián, amelyet 1938 óta megtartottak. A rendezvény rekordszámú, hatszáztizennégy statisztikus részvételével zajlott le, akik ötvenöt országból érkeztek. Egyidejüleg az ENSZ Statisztikai Világkongresszusára és féltucatnyi más szervezet (egyebek mellett az Ökonometriai Társaság, az Amerikai Statisztikai Társaság és a Nemzetközi Népességtudományi Unió) ülésére is sor került. Ezen a kora öszi konferenciasorozaton dőlt el, hogy az IIS a „statisztika nemzetközi akadémiájává”, elsődlegesen tudományos szervezetté válik, és egyéb funkcióit a hivatalos szervezetekre ruházza át. Ekkor vezették be a rendes és a tiszteletbeli tagság mellé a hivatalvezetők számára az ex officio tagság intézményét. (Nem mellékesen: ez még Thirring Gusztáv ötlete volt 1928-ból.) A magyar szakemberek Washingtonban, az amerikai statisztikai intézet 
géptermeiben ismerkedtek meg az IBM (International Business Machines) által kifejlesztett új típusú feldolgozó masinákkal (Elekes-Bene [1947] 447-450., 468-469. old.). ${ }^{17}$ Szintén az amerikai fővárosban került sor a Népességtudományi Unió közgyülésére, amelyen Elekes Dezsőt, Horváth Róbertet, Laky Dezső́t, Schneller Károlyt és Thirring Lajost az egyéni tagok sorába választották.

\section{Irodalom}

BLENCK, E. [1897]: Ernst Engel. Bulletin de l'Institut International de Statistique. Tome 10. No. 2. pp. 135-150. http://gallica.bnf.fr/ark:/12148/bpt6k61562c/f143.table

BoKOR G. [1896]: A magyar hivatalos statisztika fejlödése és szervezete. Pesti Könyvnyomda Részvénytársaság. Budapest.

BorostyÁNi N. [1876a]: A nemzetközi Budapest. Vasárnapi Ujság. 23. évf. 36. sz. 569-570. old. http://epa.oszk.hu/00000/00030/01174/pdf/01174.pdf

BorostYÁNI N. [1876b]: Statisztikusok és őstörténészek köreben. Vasárnapi Ujság. 23. évf. 37. sz. 585. old. http://epa.oszk.hu/00000/00030/01175/pdf/01175.pdf

BRIAN, E. [1990]: Bibliographie des comptes rendus officiels du congrès international de statistique (1853-1878). In: Annales de Démographie Historique 1990. pp. 469-479. http://www.persee.fr/doc/adh_0066-2062_1990_num_1990_1_1788

BRown, S. [1854]: Report of the proceedings at the Statistical Congress, held at Brussels, $19^{\text {th }}$ to $22^{\text {nd }}$ September, 1853. The Assurance Magazine, and Journal of the Institute of Actuaries. Vol. 4. No. 2. pp. 93-107. http://www.jstor.org/stable/pdf/41134598.pdf

BRown, S. [1858]: Report on the International Statistical Congress, held at Vienna, September, 1857. Journal of the Statistical Society of London. Vol. 21. No. 1. pp. 1-17. http://www.jstor.org/stable/pdf/2338209.pdf

BRown, S. [1864]: Report on the Fifth International Statistical Congress, held at Berlin, Sept. $6^{\text {th }}$ to $12^{\text {th }}, 1863$. The Assurance Magazine, and Journal of the Institute of Actuaries. Vol. 11. No. 4. pp. 195-224. http://www.jstor.org/stable/pdf/41135021.pdf

BRown, S. [1868]: Report on the Sixth International Statistical Congress, held at Florence, From $29^{\text {th }}$ September to $5^{\text {th }}$ October, 1867. Journal of the Statistical Society of London. Vol. 31. No. 1. pp. 11-24. http://www.jstor.org/stable/pdf/2338882.pdf

Brown, S. [1869]: Report on the Seventh International Statistical Congress, held at The Hague, $6^{\text {th }}-11^{\text {th }}$ September, 1869. Journal of the Statistical Society of London. Vol. 32. No. 4. pp. 391410. http://www.jstor.org/stable/pdf/2338752.pdf

BRown, S. [1872]: Report on the Eighth International Statistical Congress, held at St. Petersburg, $22^{\text {nd }} / 10^{\text {th }}$ August to $29^{\text {th }} / 17^{\text {th }}, 1872$. Journal of the Statistical Society of London. Vol. 35. No. 4. pp. 431-457. http://www.jstor.org/stable/pdf/2338764.pdf

BuDAPESTI HírLAP [1901a]: Statisztikusok kongresszusa. 21. évf. 269. sz. 6-7. old.

${ }^{17}$ Hazánkban az 1930-as népszámláláshoz használtak először gépeket - akkor, amikor az Egyesült Államokban már negyven éve alkalmazták azokat. Lásd erről ebben a számban: Rózsa [2017] 1174. old.

Statisztikai Szemle, 95. évfoluam 11-12. szám 
BudAPESTI HíRLAP [1901b]: Statisztikai kongresszus. 21. évf. 274. sz. 9-10. old.

ElekEs D. - BeNE L. [1947]: A Nemzetközi Statisztikai Konferenciák tanulságai. A Nemzetközi Statisztikai Intézet 1947. szeptember 8-16-a között Washingtonban megtartott XXV. ülésszaka, az Egyesült Nemzetek statisztikai világkongresszusa és a többi ezekkel kapcsolatos ülések. Magyar Statisztikai Szemle. 25. évf. 11-12. sz. 447-469. old.

FöVÁROSI LAPOK [1876]: A statisztikai kongresszus. 13. évf. 200. sz. 941. old.

GERLÓCZY Zs. (szerk.) [1895]: Jelentés az 1894. szeptember hó 1-töl 9-ig Budapesten tartott VIIIik nemzetközi közegészségi és demografiai congressusról és annak tudományos munkálatairól. I. köt. Pesti Könyvnyomda-Részvénytársaság. Budapest.

Hammaск, J. T. [1861]: Report to the Statistical Society on the proceedings of the Fourth Session of the International Statistical Congress, held in London, July, 1860. Journal of the Statistical Society of London. Vol. 24. No. 1. pp. 1-21. http://www.jstor.org/stable/pdf/2338408.pdf

JURASCHEK, F. vON [1909]: Karl von Theodor Inama-Sternegg, 1843-1909 [sic!]. Bulletin de l'Institut International de Statistique. Tome 18 . No. $1 . \quad$ pp. 639-659. http://gallica.bnf.fr/ark:/12148/bpt6k615809/f654.image

KÁRMÁN V. [1969]: A nemzetközi demográfiai kongresszusok megalakulásának 90. évfordulójára. Demográfia. 12. évf. 1-2. sz. 177-186. old.

KELETI K. [1874]: A mezögazdasági statistika a nemzetközi kongressusokon. Athenaeum. Budapest.

KeLETI K. [1875]: Quetelet emlékezete. Athenaeum. Budapest.

KelETI K. - Hunfalvy J. [1873]: Jelentés az 1872. augustus havában Szent-Pétervárott tartott VIII. nemzetközi statistikai kongressus tanácskozmányai-és határozataiból. Athenaeum. Pest.

Konkoly Thege Gy. [1929]: A nemzetközi gazdaságstatisztikai egyezmény és Magyarország gazdaságstatisztikája. Magyar Statisztikai Szemle. 7. évf. 9. sz. 1000-1008. old.

KonKoly THEGE Gy. [1937]: Olasz-magyar kapcsolatok a statisztika terén. Magyar Statisztikai Szemle. 15. évf. 4. sz. 251-254. old.

LEVI, L. [1856]: Resume of the Second Session of the International Statistical Congress held at Paris, September, 1855. Journal of the Statistical Society of London. Vol. 19. No. 1. pp. 1-11. http://www.jstor.org/stable/pdf/2338170.pdf

Magyar Statisztikai Szemle [1938]: A Nemzetközi Statisztikai Intézet csonka XXIV. (prágai) ülésszaka. 16. évf. 8. sz. 853-854. old.

Mike Gy. [1947]: A Központi Statisztikai Hivatal 1945-1946. évi munkássága. Magyar Statisztikai Szemle. 25. évf. 1-2. sz. 51-58. old.

MisCHLER, E. [1892]: Handbuch der Verwaltungs-Statistik. Erster Band. Allgemeine Grundlagen der Verwaltungs-Statistik. Cotta. Stuttgart.

Mouat, F. J. [1876]: Preliminary Report of the Ninth International Statistical Congress, held at Buda-Pesth, from $1^{\text {st }}$ to $7^{\text {th }}$ September, 1876. Journal of the Statistical Society of London. Vol. 39. No. 4. pp. 628-647. http://www.jstor.org/stable/pdf/2339156.pdf

NIXON, J. W. [1960]: A History of the International Statistical Institute 1885-1960. International Statistical Institute. Hague. https://www.isi-web.org/images/publ/J.W.Nixon.pdf

Pesti NAPLÓ [1901]: Statisztikusok gyülése. 52. évf. 269. sz. 2-3. old.

RÉVFALVI M. [1998]: A magyar statisztikai szolgálat a két világháború között (1918-1944). In: Dányi D. - Nyitrai F.-né (szerk.): Tanulmányok a magyar statisztikai szolgálat történetéböl. Központi Statisztikai Hivatal. Budapest. 97-150. old. 
RózSA G. [2017]: A hivatalos magyar népszámlálások és más nagy népesség-összeírások, 18702016 - I. rész (1870-1949). Statisztikai Szemle. 95. évf. 11-12. sz. 1159-1180. old. https://doi.org/10.20311/stat2017.11-12.hu1159

SCHNELleR K. [1936]: A berlini Nemzetközi Népességtudományi Kongresszus. Ludvig István Könyvnyomdája. Miskolc.

StemerdinK, G. J. (ed.) [2003]: Members of the International Statistical Institute. A Cumulative List for the Period 1885-2002. A publication to celebrate 150 years of international statistical congresses. ISI. Voorburg. isi.cbs.nl/iamamember/Books/Members_of_the_ISI_1885-2002.pdf

SzABÓ B. [1942]: A Nemzetközi Statisztikai Intézet ülése Budapesten 40 évvel ezelött. Magyar Statisztikai Szemle. 20. évf. 1. sz. 43-46. old.

SzILÁGyi Gy. [2012]: A Nemzetközi Statisztikai Intézet (ISI) múltja és jelene. Statisztikai Szemle. 90. évf. 7-8. sz. 733-742. old.

THIRRING L. [1958]: Nemzetközi demográfiai értekezletek, népességi világkongresszusok. Demográfia. 1. évf. 2-3. sz. 311-318. old.

THIRRING L. [1978]: Visszaemlékezések az egykori statisztikai társaságra és népességtudományi csoportra. Kézirat.

VASÁRNAPI UjSÁG [1876a]: A nemzetközi statisztikai kongresszus. 23. évf. 36. sz. 570-571. old. http://epa.oszk.hu/00000/00030/01174/pdf/01174.pdf

VASÁRNAPI UJSÁG [1876b]: Visszatekintés a IX. nemzetközi statisztikai kongresszusra. 23. évf. 48. sz. 753-755. old. http://epa.oszk.hu/00000/00030/01186/pdf/01186.pdf

\section{Summary}

Since 1867, the very beginning of its history, the Hungarian official statistics has been the part of international statistical life, according to the intentions of Károly Keleti, founder and head of the HCSO (Hungarian Central Statistical Office). For 150 years, Hungarian experts have been involved in international scientific discourse, and Hungarian and foreign statisticians have monitored each other's work. Relations were soon established with all major international organizations, furthermore, three Hungarian scientists, including Keleti himself, participated in the establishment of the ISI (International Statistical Institute). The $9^{\text {th }}$ and last International Statistical Congress in 1876 and the $8^{\text {th }}$ ISI Conference in 1901 were held in Budapest. The paper reviews the developments in this field in the first eighty years of existence of the HCSO. 